\title{
The Implementation Guidelines of Digital Document Management System for Malaysia Public Sector: Expert Review
}

\author{
Azlina Ab Aziz ${ }^{\#}$ Zawiyah Mohammad Yusof ${ }^{\#}$ Umi Asma Mokhtar", Dian Indrayani Jambari ${ }^{\#}$ \\ ${ }^{\#}$ Faculty of Information Science and Technology, Universiti Kebangsaan Malaysia, Bangi, Malaysia \\ E-mail: azlinaabaziz79@gmail.com; zawiy@ukm.edu.my;umimokhtar@ukm.edu.my;dian@ukm.edu.my
}

\begin{abstract}
Digital Document Management System (DDMS) is a system adopted by the Malaysian Public sector for managing documents and records. Despite giving many benefits, the adoption of the system is still below satisfaction. A guideline should be in place to accelerate the adoption rate of such a system. Accordingly, a guideline for DDMS implementation is proposed as was suggested in a previous study involving 439 DDMS users by the same authors. The proposed guidelines consist of 6 main factors which are: system capability; implementation policy; security, training; awareness programs, and top management/team members (colleague) supports. This paper aims to verify the content of the proposed guidelines in order to seek for its suitability in the Malaysian public sector context. Data was collected via a face-to-face interview with four panels of experts (practitioners) who have vast experience in DDMS implementation. The finding thence confirmed and verified the content of the proposed guidelines. The proposed guidelines is expected to assist the DDMS implementation team especially the three leading agencies such as the Malaysian Administrative Modernization and Management Planning Unit (MAMPU), Chief Government Security Office (CGSO) and the National Archives of Malaysia (NAM) in coordinating and planning for the implementation of DDMS initiative at the agencies level vis-a-vis increase the level of user adoption. This guideline also can be used as a reference to develop a detailed DDMS implementation policy by the committee and the project team.
\end{abstract}

Keywords - electronic document and records management system; DDMS implementation; public sector; information system.

\section{INTRODUCTION}

The Digital Document Management System (DDMS) is one of the initiatives of the Malaysian government for projects under the e-Government Entry Points Projects (EPP), which is striving for a paperless environment [1]. The project is being implemented in stages beginning in the year 2013. The project was executed to enhance the delivery of services and record-keeping and improve the transparency of government via the use of Information Communication and Technology (ICT) [2]. DDMS caters for document and records management services based on the concept of electronic records life cycle from creation, through storage, maintenance, and disposal. The development of DDMS has also complied with the electronic records management criteria set forth by MS ISO 16175-2: 2012 Information and Documentation - Principles and functional requirements for records in electronic office environments, thus making the system meets the international standard.

DDMS offers a wide range of benefits. These are reduced paper usage, speed up public records access, avoid loss of records, and facilitate the transfer of records to archive [3]. DDMS implementation also provides potential solutions to enhance the efficiency of public sector electronic records management, improve services, reduce storage space and integrate or eliminate duplication of work in government offices. The system is protected with the government ICT security protocols to ensure that government's documents and records are preserved. In line with the government's desire to provide readily available and efficient access to public records, the system is expected to be further extended to all agencies in the public sector by the year 2020.

DDMS has a significant impact on the management of public electronic records. Unlike the conventional environments (generally limited to filing activities) electronic environment becomes the responsibility of each staff irrespective of hierarchy. Concerning this, involvement at the user-level is essential to ensure the success of DDMS implementation. Thus, a good implementation strategy needs to be carefully planned to increase user adoption of the system which should work hand in hand with policy and guidelines. The implementation of DDMS involves a long and complicated process that influence the way of working at all levels. Therefore, change management should be incorporated.

In an earlier preliminary survey by these authors revealed that DDMS performance in the Malaysian public sector is 
still embracing hurdles in terms of low usage. The implementation was also without coordination [4] where most agencies fond of writing their policy and guidelines [5]. Given this, there is a need to develop DDMS implementation guidelines for the Malaysian public sector which can be applied and coordinated to all implementing agencies. The proposed guidelines are expected to serve as a guide for implementing the DDMS effectively and increase the adoption rate of the system among the user in the Malaysian public sector.

\section{MATERIAL AND METHOD}

The DDMS implementation guidelines developed in this paper are a result of previous research conducted earlier by these authors [6] which examined the intention to adopt DDMS among 439 users from 27 agencies in the public sector. The analysis from the earlier study showed that 4 factors were adapted from the Unified Theory of Acceptance and Use of Technology (UTAUT) theory, while another 3 from external factors. All these 7 factors were significant with the intention to adopt DDMS in the Malaysian public sector (analyzed using the Structural Equation Modelling (SEM) approach). The factors are as listed in Table 1.

\section{A. Guidelines Development}

TABLE I

FACTORS INFLUENCING DDMS ADOPTION

\begin{tabular}{|c|c|}
\hline Factors & Definition \\
\hline \multicolumn{2}{|l|}{ Factors from UTAUT } \\
\hline $\begin{array}{l}\text { Performance Expectancy } \\
\text { [7]-[16] }\end{array}$ & $\begin{array}{l}\text { "Involves the situation in which the system's users believe that DDMS can improve their job } \\
\text { performance." }\end{array}$ \\
\hline $\begin{array}{l}\text { Effort Expectancy } \\
{[7]-[15],[17]}\end{array}$ & "Involves the situation in which the system's users believe that DDMS is easy to use." \\
\hline $\begin{array}{l}\text { Social Influence } \\
\text { [7]-[12], [14], [15], [18], [19] }\end{array}$ & "Individuals can be influenced by the attitudes and behaviors of other individuals and vice versa." \\
\hline $\begin{array}{l}\text { Facilitating Condition } \\
{[7]-[14],[20]-[22]}\end{array}$ & $\begin{array}{l}\text { "The role of technical infrastructure and organization to support the DDMS implementation } \\
\text { (infrastructure, training, and technical support)" }\end{array}$ \\
\hline \multicolumn{2}{|l|}{ External Factors } \\
\hline $\begin{array}{l}\text { Perceive Value of Records } \\
\text { [23], [24] }\end{array}$ & $\begin{array}{l}\text { "Involves the situation in which the system's users believe that document and records are valuable and } \\
\text { are worthy to be stored" }\end{array}$ \\
\hline $\begin{array}{l}\text { Policy } \\
{[8],[15],[20],[25]-[27]}\end{array}$ & $\begin{array}{l}\text { "Involves the situation in which the system's users believe that policy can provide a way of action to } \\
\text { guide and determine current and future decisions." }\end{array}$ \\
\hline $\begin{array}{l}\text { Security } \\
{[15],[23],[28]-[32]}\end{array}$ & $\begin{array}{l}\text { "Involves the situation in which the system's users believe that the use of technology can ensure the } \\
\text { safety of documents and records." }\end{array}$ \\
\hline
\end{tabular}

Such a finding indicates that there is a need that warrants the development of DDMS implementation guidelines based on the identified and significant seven factors. This is in line with research conducted by [33] and [34]. The proposed guidelines can serve as an essential guide to the DDMS implementation team to address the problem of user rejection, thus, increase the adoption rate of the application. The proposed guidelines are also developed to provide solutions for the issues and challenges that have been raised by the various implementing agencies.

The development of DDMS implementation guidelines has considered two criteria which are, the significant factors and existing standards or procedures.

1) The Significant Factors: The proposed guidelines incorporate terms that are easy to understand. Although the original 7 significant factors are mapped to an easy-tounderstand factor (following this, only 6 factors are considered as the result of two factors are combined), but the definitions and features of those factors are preserved. Fig. 1 depicts the mapping between the factors influencing DDMS adoption and the proposed guidelines of DDMS implementation for the Malaysian public sector.

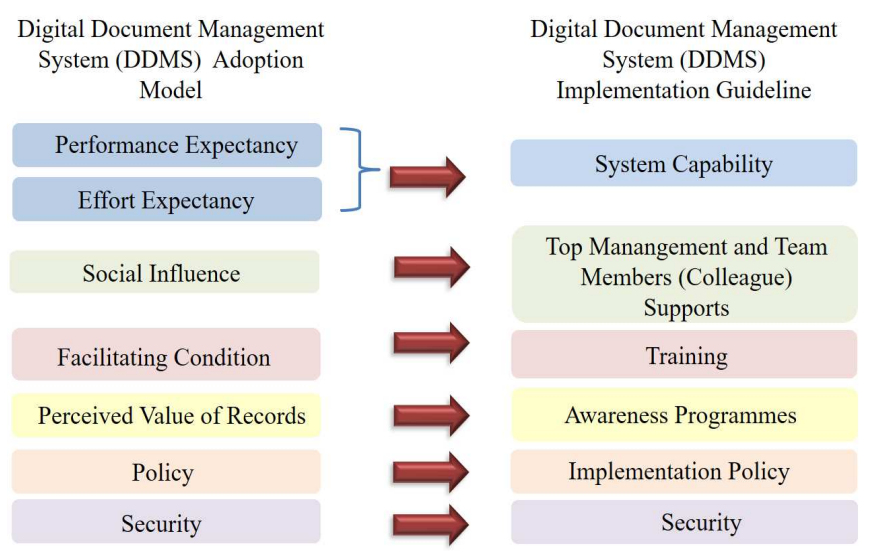

Fig. 1: Mapping between research findings on DDMS Adoption and DDMS implementation guidelines in the Malaysian public sector

2) Existing Standards and Procedures: The implementation of DDMS involves various roles and various organizations; therefore, the development also takes into account the Malaysian public sector project management standards and procedures to cater to the needs and requirements. The development also refers to existing standards, procedures, and guidelines of other countries [35]-[39]. 


\section{B. Guidelines Contents}

The proposed DDMS implementation guidelines consist of 6 new main factors as shown in Fig. 2 which are i) system capability; ii) implementation policy; iii) security iv) training; v) awareness program and vi) top management and team members (colleague) supports. A detailed description of each factor is discussed in the findings and analysis section.

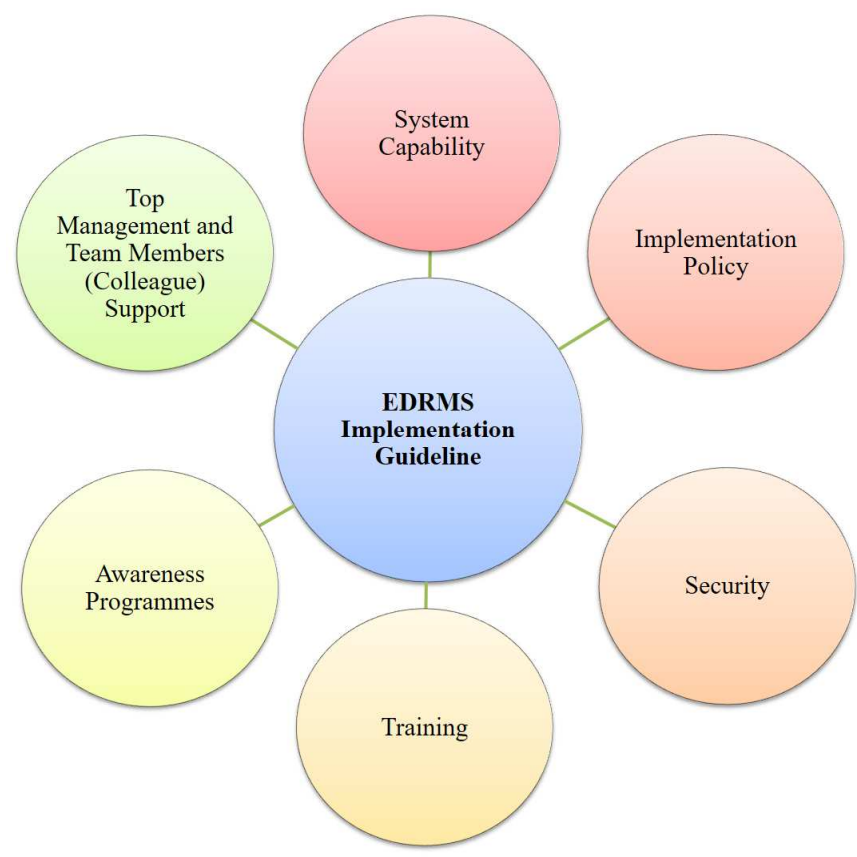

Fig. 2: Factors in DDMS Implementation Guidelines

\section{Research Method}

The purpose of the expert review was to get constructive comments, opinions and to verify whether the proposed guideline meets the standard requirement and suitable for the context of study which is the Malaysian public sector. The expert review was carried out based on 4 steps, as shown in Fig.3.

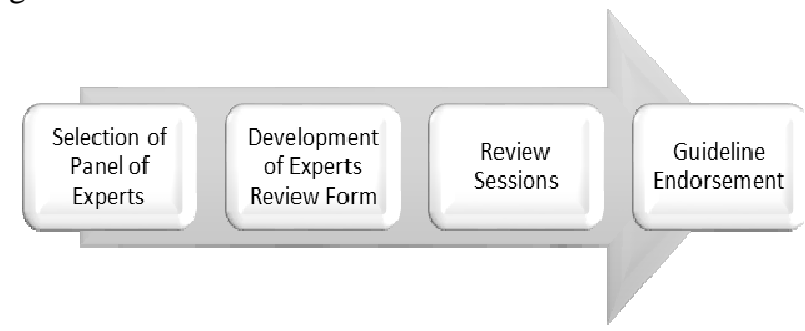

Fig. 3: Steps in Experts Review

The first step was the selection of a panel of experts. The selection was based on three criteria such as 1) involvement in the strategic planning and policy development of DDMS; 2) knowledgeable and have vast experience concerning DDMS implementation in the public sector and 3) the readiness to participate in the research. A total of four experts ( 2 from MAMPU, 1 from NAM and 1 from CGSO) were able to participate in this expert review. These three agencies were selected based on their role as the leading agencies in executing the implementation of DDMS. The expert's criteria are as depicted in Table 2.
TABLE II

EXPERTS CRITERIA

\begin{tabular}{|c|l|c|c|}
\hline & \multicolumn{1}{|c|}{ Position } & Experience & Agency \\
\hline E1 & $\begin{array}{l}\text { Information Management Expert (Top } \\
\text { management) }\end{array}$ & 35 years & MAMPU \\
\hline E2 & $\begin{array}{l}\text { Information Management Expert (Senior } \\
\text { management) }\end{array}$ & 12 years & MAMPU \\
\hline E3 & $\begin{array}{l}\text { Information Management Expert } \\
\text { (Operational) }\end{array}$ & 12 years & CGSO \\
\hline E4 & $\begin{array}{l}\text { National Archives of Malaysia Expert } \\
\text { (Management) }\end{array}$ & 20 years & NAM \\
\hline
\end{tabular}

The second step was the development and preparation of expert review form that was used to gather feedback data and to confirm the content of the guidelines eventually. Experts were asked to respond based on three questions. (1) Does the Government have any existing DDMS implementation guidelines to increase the adoption in the Malaysian public sector?; (2) Do the DDMS implementation guidelines are required by the Government (in general) and the DDMS implementation team (in particular) to improve the existing implementation thus ensuring the successful implementation of this application?; (3) Do the recommendations or proposed guidelines on empirical studies involving DDMS users are appropriate in the real environment?

Lastly, in the third step, the complete proposed guidelines attached to the expert review form were presented to the panel of experts in a face-to-face approach session. The experts were requested to verify the format, flow, content of the document and its suitability with the Malaysian public sector context. All comments and opinions were taken into account and corrected before being presented again during the second session. Besides the six factors, the implementation governance was advised to be added as part of the guideline's content by E1, and E3 supported the opinion. Finally, all the panel experts were unanimously agreed and endorsed the updated version of DDMS implementation guidelines (after all corrections and improvements are made).

\section{RESUlTS AND DISCUSSION}

This section discusses the result of the study, which is the contents of the updated DDMS implementation guidelines that have been approved and endorsed by the experts. The final guidelines are produced after considering the comments and suggestions from the experts during the review session.

\section{A. Implementation Governance}

The proposed governance structure of DDMS implementation consists of the Project Steering Committee, Project Technical Committee, Project owner, Subject Matter Experts (SME) and Implementation Team (at agencies level). Each committee/project team needs to understand their roles and responsibilities to ensure that the DDMS implementation works smoothly and effectively. All agencies are encouraged to set up a DDMS governance structure at the agency level to ensure that all functions are aligned and well implemented. The description of each committee and working team with the scope of the task is as set out in Table 3. 
TABLE III

ROLE AND JOB SCOPE OF IMPLEMENTATION TEAM

\begin{tabular}{|c|c|}
\hline Role & Job Scope \\
\hline Project Steering Committee & $\begin{array}{l}\text { - Determine the direction and implementation strategy of the project; } \\
\text { - Monitor the overall project implementation status; } \\
\text { - Monitor and coordinate project financial flows equivalent to project progress; } \\
\text { - Approving project payment; } \\
\text { - Consider and approving proposed contract enforcement terms such as penalties, an extension of time, and } \\
\text { contract termination; } \\
\text { - Solve project-related policy issues; } \\
\text { - Consider and approve the proposal for any project-related issues to be addressed by the Project Technical } \\
\text { - Committee; } \\
\text { - Approving and verifying each stage of the project implementation; } \\
\text { - Reporting project progress status to Government IT and Internet Committee }\end{array}$ \\
\hline Project Technical Committee & $\begin{array}{l}\text { - Monitor and ensure project execution meets the scope and timetable of the project; } \\
\text { - Reviewing and selecting project submissions meeting the requirements set forth; } \\
\text { - Review the policy issues during the implementation of the project and certify the proposed solution to the Project } \\
\text { Steering Committee for approval; } \\
\text { - Review and acknowledge the terms of the enforcement of contract terms to the Project Steering Committee; } \\
\text { - Provide solutions to technical issues during project implementation; } \\
\text { - Review a project submission to the Project Steering Committee for approval; and } \\
\end{array}$ \\
\hline Project Owner & $\begin{array}{l}\text { - Design and prepare direction and strategy project; } \\
\text { - Identify project activities and implementation schedules in detail; } \\
\text { - Implement projects following the scope and timetable; } \\
\text { - Require the enforcement of contract terms (if applicable) to the Project Team, Project Technical Committee and } \\
\text { Project Steering Committee; } \\
\text { - Identify issues and problems of project implementation and solution proposals; } \\
\text { - Monitor the progress of project implementation based on agreed contract and schedule; and } \\
\text { - Reviewing and selecting project submissions through a quality assurance process and specified standards. }\end{array}$ \\
\hline $\begin{array}{l}\text { Subject Matter Expert (SME) } \\
\text { for Physical Protection } \\
\text { Security, Document, Personnel, } \\
\text { and ICT Security Management }\end{array}$ & $\begin{array}{l}\text { - Involved in system requirements and specification studies as well as testing sessions (UAT, PAT, and FAT); } \\
\text { - Involved in the implementation of the system as a pioneering agency; } \\
\text { - Providing advice on the management of records, laws, and regulations in force; and } \\
\text { - Coordinate consultancy services activities and implement departmental record management programs and } \\
\text { activities such as record management training/briefing, file classification workshop, and record disposal } \\
\text { workshop. }\end{array}$ \\
\hline $\begin{array}{l}\text { Implementation Team } \\
\text { (Agencies Level) }\end{array}$ & $\begin{array}{l}\text { - Manage the implementation of DDMS in agencies level involving: user training, implementation programs, and } \\
\text { awareness/ change management programs; } \\
\text { - Preparing Progress Report (monthly usage); } \\
\text { - Report the problem of using the system. } \\
\text { - Recommendations from time to time regarding systems improvement: }\end{array}$ \\
\hline
\end{tabular}

\section{B. System Capability}

System users always look forward to a user-friendly and easy-to-use system to improve their routine task performance [40]. Among the system criteria to be considered by developers and system administrators from time to time are as set out in Table 4.

TABLE IV

SYSTEM CRITERIA

\begin{tabular}{|l|l|}
\hline \multicolumn{1}{|c|}{ Item } & \multicolumn{1}{c|}{ Criteria } \\
\hline $\begin{array}{l}\text { Benefits of } \\
\text { Completing } \\
\text { the daily } \\
\text { task }\end{array}$ & $\begin{array}{l}\text { - Completing routine tasks more easily and } \\
\text { quickly; }\end{array}$ \\
\hline Easy to Use & - Smproved performance; and \\
& $\begin{array}{l}\text { - Able to reduce or remove workloads; } \\
\text { - Provide a user-friendly system interface } \\
\text { (clear and easy to understand); and } \\
\text { - Easy to understand and learn (included with } \\
\text { user manuals). }\end{array}$ \\
\hline Language & $\begin{array}{l}\text { The language used should be of quality and } \\
\text { free from grammatical and spelling errors. }\end{array}$ \\
\hline
\end{tabular}

\section{Implementation Policy}

DDMS implementation policies need to be developed, coordinated, and enforced by all implementing agencies to ensure smooth implementation [41]-[43]. Inputs from MAMPU, NAM, CGSO and agency representatives (to identify best practices) are required to produce a complete and accurate implementation policy. The proposed policy implementation is as set out in Table 5.

TABLE V

IMPLEMENTATION POLICY CRITERIA

\begin{tabular}{|l|l|}
\hline Item & Criteria \\
\hline DDMS & To develop written policies/procedures \\
Implementation & $\begin{array}{l}\text { regarding the implementation of DDMS. The } \\
\text { policy }\end{array}$ \\
& $\begin{array}{l}\text { policy should include the following features: } \\
\text { requirements; }\end{array}$ \\
& $\begin{array}{l}\text { incorporating DDMS guidelines in detail; } \\
\text { adjustable based on agency environment }\end{array}$ \\
& - Easy to understand; and \\
& - Easy to implement \\
\hline
\end{tabular}




\begin{tabular}{|l|l|}
\hline Existing Policy & $\begin{array}{l}\text { Update existing policies that are still } \\
\text { relevant and usable }\end{array}$ \\
\hline $\begin{array}{l}\text { Policy } \\
\text { Distribution and } \\
\text { Enforcement }\end{array}$ & $\begin{array}{l}\text { Distribute usage instructions signed by the } \\
\text { Minister and include attachment of } \\
\text { instructions from MAMPU (signed by the } \\
\text { head director of MAMPU); }\end{array}$ \\
& $\begin{array}{l}\text { Upload relevant policies within agency } \\
\text { websites or DDMS announcement space; } \\
\text { Enforce the use of established policies to } \\
\text { ensure compliance with these policies; and }\end{array}$ \\
& $\begin{array}{l}\text { Monitor policy adoption by implementing } \\
\text { agencies }\end{array}$ \\
\hline
\end{tabular}

\section{Security}

Security is a frequent issue that had been raised by the system's users [15],[23],[31]. The adoption of the system will increase if the user's confidence in system security is high. Among the items to be emphasized are as set out in Table 6.

TABLE VI

PROPOSED SECURITY IMPLEMENTATION

\begin{tabular}{|c|c|}
\hline Item & Activities \\
\hline $\begin{array}{l}\text { System } \\
\text { Development } \\
\text { Characteristic }\end{array}$ & $\begin{array}{l}\text { - Ensuring development of the system meets } \\
\text { the security controls as contained in the } \\
\text { Safety Directive; and } \\
\text { - Meeting electronic records management } \\
\text { requirements and guidelines released by } \\
\text { NAM: } \\
\text { National Archive Act } 2003 \text { [Act 629] } \\
\text { MS ISO 16175-2:2012 }\end{array}$ \\
\hline $\begin{array}{l}\text { File Access } \\
\text { Limit }\end{array}$ & $\begin{array}{l}\text { - Creates security control and access to } \\
\text { physical files and records in DDMS } \\
\text { applications at all levels (individuals, } \\
\text { working groups and organizations); } \\
\text { - Record access should be updated from time } \\
\text { to time (in the event of a change of role due } \\
\text { to transfer to other Divisions/Ministries, } \\
\text { service expiring, pensionable or otherwise); } \\
\text { - Make sure personal files are not included in } \\
\text { the DDMS application; and } \\
\text { - Access to project files in certain Divisions/ } \\
\text { Sections may be restricted depending on the } \\
\text { consideration of the value of the records, } \\
\text { especially in terms of security. }\end{array}$ \\
\hline $\begin{array}{l}\text { Disaster } \\
\text { Recovery } \\
\text { Plan }\end{array}$ & $\begin{array}{l}\text { - Keep records safe in the event of an } \\
\text { undesirable disaster } \\
\text { - Formulate a disaster recovery plan for each } \\
\text { involved agency; } \\
\text { - Backups should be made to applications, } \\
\text { systems and all categories of information } \\
\text { according to the suitability of the operation. } \\
\text { This is to ensure the system or information } \\
\text { recovery in the event of loss of data, disaster } \\
\text { or interference; and } \\
\text { - Duplication of applications, software, and } \\
\text { equipment should be made to maintain } \\
\text { information availability and ensure continuity } \\
\text { of service in the event of disruption or } \\
\text { damage to any equipment or system. }\end{array}$ \\
\hline Advisory & $\begin{array}{l}\text { - Provide advisory services on security } \\
\text { systems, laws and regulations that are } \\
\text { enforceable. Provide advisory services on } \\
\text { security systems, laws and regulations that } \\
\text { are enforceable. }\end{array}$ \\
\hline
\end{tabular}

\section{E. Training}

User training is one of the essential factors that should be emphasized by the implementing agency [15],[44]. DDMS application should be implemented consistently to increase the efficiency and utilization skills. Training should be carried out based on user criteria because the fundamental approach is different. Training should also be carried out continuously to meet the needs of new users that are increasing from time to time. Table 7 shows the proposed training implementation.

TABLE VII

PROPOSED TRAINING IMPLEMENTATION

\begin{tabular}{|c|c|}
\hline Type of Training & Implementation \\
\hline $\begin{array}{l}\text { Training for Top } \\
\text { Management }\end{array}$ & $\begin{array}{l}\text { - One-to-one session in the officer's room } \\
\text { with the presence of the personal assistant } \\
\text { (PA) as a facilitator; } \\
\text { - Exercise 'hands-on'; } \\
\text { - Involving certain modules only (which } \\
\text { corresponds to positions and scope of } \\
\text { work) other modules are managed by the } \\
\text { personal assistant; and } \\
\text { - Duration: } 1 \text { to } 2 \text { hours per session }\end{array}$ \\
\hline $\begin{array}{l}\text { Training for } \\
\text { Record Managers }\end{array}$ & \multirow{4}{*}{$\begin{array}{l}\text { - Implemented in stages and persistently. } \\
\text { Agency-level training plans should be } \\
\text { provided; } \\
\text { - Implemented in a well-equipped training } \\
\text { room with computers and internet } \\
\text { networks; } \\
\text { - Executed in groups (range between } 20 \\
\text { and } 30 \text { participants); } \\
\text { - Exercise 'hands-on'; } \\
\text { - Training Manual - Guided by manual / } \\
\text { system usage procedures based on user } \\
\text { categories; } \\
\text { - Exercises for each category are } \\
\text { implemented separately; } \\
\text { - Duration: } 2 \text { days ( } 8 \text { am to } 5 \text { pm); and } \\
\text { - Assessment of training should be carried } \\
\text { out to determine the effectiveness of the } \\
\text { training. }\end{array}$} \\
\hline $\begin{array}{l}\text { Training for } \\
\text { System Managers }\end{array}$ & \\
\hline $\begin{array}{l}\text { Training for } \\
\text { Information } \\
\text { Officers }\end{array}$ & \\
\hline User Training & \\
\hline $\begin{array}{l}\text { Repeated } \\
\text { Training (as } \\
\text { requested by the } \\
\text { users) }\end{array}$ & $\begin{array}{l}\text { - Implemented based on user demand; } \\
\text { - Engage only certain modules; and } \\
\text { - Executed in groups }\end{array}$ \\
\hline $\begin{array}{l}\text { Help Desk } \\
\text { (Technical } \\
\text { Supports) }\end{array}$ & $\begin{array}{l}\text { - Creating online helpdesk at each agency; } \\
\text { - Provide technical assistance online } \\
\text { (immediate assistance); } \\
\text { - Record user complaints; } \\
\text { - Extend complaints to the responsible } \\
\text { division; and } \\
\text { - Monitor the actions taken. }\end{array}$ \\
\hline
\end{tabular}

\section{F. Awareness Program}

Awareness programs need to be carefully planned to increase the adoption of the system [44] and acknowledge the users on the benefits earned by using DDMS. The programs should also be able to attract users to use the system consistently and continuously. Among the proposed programs that can be implemented to increase awareness and consumer adoption of DDMS areas listed in Table 8. 
However, the programmes depend on the needs and goals of each implementing agency.

TABLE VIII

PROPOSED AWARENESS PROGRAMMES

\begin{tabular}{|c|}
\hline Programmes/Activities \\
\hline $\begin{array}{l}\text { Briefing on the introduction of DDMS concepts that include: } \\
\text { - records management process and lifecycle; } \\
\text { - the role of system users (based on user categories); } \\
\text { the importance of preserving and storing documents and } \\
\text { records into the system; and } \\
\text { - Benefits of using DDMS. }\end{array}$ \\
\hline $\begin{array}{l}\text { Meeting or engagement session with the involved implementing } \\
\text { agencies (especially those with a low percentage of use): } \\
\text { - Conducting field sessions to identify problems encountered; } \\
\text { - Provide briefings on actions that can be taken to resolve the } \\
\text { problem; and }\end{array}$ \\
\hline DDMS Open Day \\
\hline $\begin{array}{l}\text { DDMS implementation workshop involving all representatives of } \\
\text { implementing agencies }\end{array}$ \\
\hline Regular and continuous user training \\
\hline $\begin{array}{l}\text { Awarded in the form of consolation prizes and certificate of } \\
\text { appreciation based on the following categories (every three } \\
\text { months): } \\
\text { - Ministries that demonstrate good and consistent performance; } \\
\text { - Section / Unit with active and consistent usage; and } \\
\text { - Most active users }\end{array}$ \\
\hline $\begin{array}{l}\text { Poster and brochure distribution: } \\
\text { - Poster and brochure related to DDMS are printed and } \\
\text { distributed to all implementing agencies (Ministries and } \\
\text { Departments / Agencies); } \\
\text { Pasting posters at: } \\
\text { a. Focus areas such as the lobby, agency lifts, and cafes; } \\
\text { b. Training room; and } \\
\text { c. All departments involved }\end{array}$ \\
\hline
\end{tabular}

G. Top Management and Team Members(colleague) Support

The involvement and support of top management are one of the main factors contributing to the success of DDMS implementation [15],[44]. Top management plays an essential role in managing the organizations especially in the first phase of DDMS implementation. Good leadership can support and control the project at all levels ranging from the ground up to the highest level. Support between team members is also essential to ensure that DDMS is used extensively. Table 9 shows a proposed activity to increase the support of top management and team members.

TABLE IX

PROPOSED IMPLEMENTATION

\begin{tabular}{|l|l|}
\hline \multicolumn{1}{|c|}{ Item } & \multicolumn{2}{|c|}{ Implementation } \\
\hline Top Management: \\
\hline $\begin{array}{l}\text { Top } \\
\text { Management }\end{array}$ & $\begin{array}{l}\text { Top Management in implementing agencies } \\
\text { should: } \\
\text { - be clear on the vision and the direction of } \\
\text { the DDMS implementation; } \\
\text { assess the agency's capabilities in terms of } \\
\end{array}$ \\
& $\begin{array}{l}\text { human resources, expertise, and } \\
\text { infrastructure to support the DDMS } \\
\text { implementation; }\end{array}$ \\
\hline
\end{tabular}

\begin{tabular}{|c|c|}
\hline & $\begin{array}{l}\text { - involve directly or indirectly with } \\
\text { programs/activities related to DDMS } \\
\text { implementation; } \\
\text { - allocate adequate financial and human } \\
\text { resources for the DDMS implementation; } \\
\text { - issue and distribute the instruction letter } \\
\text { signed by MAMPU's Head Director/Chief } \\
\text { Secretary; } \\
\text { - promoting usage by prioritizing the } \\
\text { implementation of DDMS; }\end{array}$ \\
\hline $\begin{array}{l}\text { DDMS } \\
\text { Implementation } \\
\text { Progress } \\
\text { Report } \\
\text { (Monitoring) }\end{array}$ & $\begin{array}{l}\text { Monitoring and progress acknowledgment is } \\
\text { implemented by: } \\
\text { - reporting Committee chaired by MAMPU's } \\
\text { top management; } \\
\text { - presentation of project progress in meetings } \\
\text { chaired by the chief secretary; and } \\
\text { - monthly performance reporting reports. }\end{array}$ \\
\hline \multicolumn{2}{|l|}{ Team Members } \\
\hline $\begin{array}{l}\text { Senior Officers } \\
\text { and Sub- } \\
\text { coordinates }\end{array}$ & $\begin{array}{l}\text { - Senior officers should encourage their } \\
\text { officers to use DDMS in their daily tasks by } \\
\text { using DDMS to: } \\
\text { a. Store and distribute daily tasks; } \\
\text { b. Prepare and distribute Division / Unit } \\
\text { meeting minutes; } \\
\text { c. Monitor the status of the assignment. } \\
\text { - Conducting knowledge-sharing sessions on } \\
\text { regular DDMS use at their respective } \\
\text { Divisions / Units; and } \\
\text { Rewarding officers who perform well and } \\
\text { consistent. }\end{array}$ \\
\hline
\end{tabular}

\section{CONCLUSIONS}

From the review session, all the experts unanimously agreed and verified that: Currently, there are no proper guidelines for the DDMS implementation in the Malaysian public sector; it is important to have guidelines to ensure the success of DDMS implementation in the Malaysian public sector; the content of the proposed guidelines is appropriate applicable and can be used as a basic guide for developing more comprehensive guidelines and synchronized to all DDMS implementing agencies; and the proposed guidelines are appropriate and suitable to be imposed in the Malaysian public sector in assisting the execution of DDMS implementation. Nonetheless, this proposed guideline is subject to revision and amendment as time pass to cater the advancement of technology, applications, procedures, and laws. Also, this guideline should be used in a complementary manner with other government-related guidelines.

\section{ACKNOWLEDGMENT}

The research was funded by Research Grant (GUP-2017046), the National University of Malaysia.

\section{REFERENCES}

[1] MAMPU, "Pelan Strategik ICT Sektor Awam Malaysia," vol. 2020, pp. 39-44, 2016.

[2] Unit Pemodenan Tadbiran Dan Perancangan Pengurusan Malaysia (MAMPU), "Digital Document Management System (DDMS)," 2014.

[3] Unit Pemodenan Tadbiran dan Perancangan Pengurusan Malaysia, "Pelaksanaan Digital Document Management System (DDMS) Sektor Awam," pp. 1-9, 2012. 
[4] U. P. T. D. P. P. M. MAMPU, "Laporan Penggunaan DDMS 2017.” 2017.

[5] M. Umi Asma' and M. Y. Zawiyah, "Electronic Records Management in the Malaysian Public Sector: The Existence of Policy," Rec. Manag. J., vol. 19, pp. 231-244, 2009.

[6] A. A. Azlina, M. Y. Zawiyah, U. A. Mokhtar, and D. I. Jambari, "A Conceptual Model for Electronic Document and Records Management System Adoption in Malaysian Public Sector," vol. 8, no. 4, pp. 1191-1197, 2018

[7] J. Seo, Y. Cho, K. Jung, and G. Gim, A Study on Factors Affecting the Intension to Use Human Resource Cloud Service, vol. 786. Springer International Publishing, 2019.

[8] K.-J. Jung, J.-B. Park, N. Q. Phan, C. Bo, and G. Gim, An International Comparative Study on the Intension to Using CryptoCurrency, vol. 553. Springer International Publishing, 2019.

[9] M. Naranjo-Zolotov et al., "Examining Social Capital and Individual Motivators to Explain the Adoption of Online Citizen Participation," Futur. Gener. Comput. Syst., 2018.

[10] Venugopal, P. Aswini, Manupati, Varela, Machado, and Putnik, Impact of UTAUT Predictors on the Intention and Usage of Electronic Health Records and Telemedicine from the Perspective of Clinical Staffs, vol. 27, no. 2. Springer International Publishing, 2018.

[11] Y. K. Dwivedi, N. P. Rana, A. Jeyaraj, M. Clement, and M. D. Williams, "Re-examining the Unified Theory of Acceptance and Use of Technology (UTAUT): Towards a Revised Theoretical Model," 2017

[12] Venkatesh, Tobergte, D. R.Curtis, and Shirley, "User Acceptance of Information Technology: Toward a Unified View," J. Chem. Inf. Model., vol. 53, no. 9, pp. 1689-1699, 2013

[13] F. Kaaki and C. Rayner, "Female Users ' Acceptance of the Electronic Document Management System (EDMS)," in Proceedings - UKSim-AMSS 7th European Modelling Symposium on Computer Modelling and Simulation, EMS 2013, 2013.

[14] S. Rahi, M. A. Ghani, F. M. Alnasera, and A. H. Ngah, "Investigating the Role of Unified Theory of Acceptance and Use of Technology (UTAUT) in Internet Banking Adoption," Manag. Sci. Lett., no. January, 2018.

[15] Muaadh, M. Y. Zawiyah, M. Umi Asma', and F. Fauzi, "Taxonomic Framework for Factors Influencing ERMS Adoption in Organisations of Higher Professional Education," J. Inf. Sci., 2018.

[16] A. Hossain, R. Quaresma, and H. Rahman, "Investigating Factors Influencing the Physicians' Adoption of Electronic Health Record (EHR) in Healthcare System of Bangladesh: An Empirical Study," Int. J. Inf. Manage., vol. 44, no. September 2018, pp. 76-87, 2018.

[17] Y. Yavwa and H. Twinomurinzi, "Impact of Culture on EGovernment Adoption Using UTAUT: A Case of Zambia," 2018 5th Int. Conf. eDemocracy eGovernment, ICEDEG 2018, pp. 356-360, 2018.

[18] T. Dimitrovski, P. Ketikidis, L. Lazuras, and P. A. Bath, "Adoption of Electronic Health Records (EHRs): A Review of Technology Acceptance Studies," Proc. 16th Int. Symp. Heal. Inf. Manag. Res. ISHIMR 2013, no. 1999, pp. 1-9, 2013.

[19] K. Magsamen-conrad, "Bridging the divide- Using UTAUT to predict multigenerational tablet.pdf," 2015.

[20] L. A. Azlan, M. Y. Zawiyah, K. Ahmad, and M. Umi Asma, "The Building Blocks of Electronic Records and Information Management Framework for Malaysia Public Agencies: Contexts And Approaches," 2018.

[21] C. M. Afonso, J. L. Roldan, M. Sanchez-franco, and M. De la O Gonzalez, "The Moderator Role of Gender in the Unified Theory of Acceptance and Use of Technology (UTAUT): A study on Users of Electronic Document Management Systems," 7th Int. Conf. Partial Least Squares Relat. Methods, pp. 1-8, 2012.

[22] Afonso, de la G. Maria, J. Roldan, and M. Sanchez-Franco, "Determinants of User Acceptance of a Local eGovernment Electronic Document Management System (EDMS)," ECEG2012Proceedings 12th Eur. Conf. e-Government ECEG, Acad. Conf. Ltd., pp. 19-28, 2012.
[23] M. J. Lewellen, "The Impact of the Perceived Value of Records on the Use of Electronic Recordkeeping Systems," Ph.D Thesis, Victoria University of Wellington, 2015.

[24] W. Pan, "The Implementation of Electronic Recordkeeping Systems: An Exploratory Study of Socio-Technical Issues," Rec. Manag. J., 2017.

[25] A. Dikopoulou and A. Mihiotis, "The Contribution of Records Management to Good Governance," TQM J., vol. 24, pp. 123-141, 2012.

[26] P. Otto and D. Nevo, "Electronic Health Records-A Simulation Model to Measure the Adoption Rate from Policy Interventions," $J$. Enterp. Inf. Manag., vol. 26, no. 1/2, pp. 165-182, 2013.

[27] Muaadh, M. Y. Zawiyah, and M. Umi Asma', A Framework for Electronic Records Management System Adoption in the Higher Professional Education: Individual, Technological and Environmental Factors, vol. 843. Springer International Publishing, 2019.

[28] A. Ghazvini and Z. Shukur, "Security Challenges and Success Factors of Electronic Healthcare System," Procedia Technol., vol. 11, no. ICEEI, pp. 212-219, 2013.

[29] B. E. Asogwa, "The Challenge Of Managing Electronic Records In Developing Countries," Rec. Manag. J., vol. 22, no. 3, pp. 198-211, 2012.

[30] K. K. Adu and P. Ngulube, "Key Threats and Challenges to the Preservation of Digital Records of Public Institutions in Ghana," Information, Commun. Soc., vol. 0, no. 0, pp. 1-19, 2016.

[31] S. K. Sharma, "Adoption of e-government Services: The Role of Service Quality Dimensions and Demographic Variables," Transform. Gov. People, Process Policy, 2015.

[32] D. Daglish and N. Archer, "Electronic personal health record systems: A brief review of privacy, security, and architectural issues," Congr. 2009 - 2009 World Congr. Privacy, Secur. Trust Manag. E-bus., pp. $110-120,2009$

[33] M. A. Faizura Haneem, "Master Data Management Adoption Model in Malaysian Local Government," Ph.D Thesis, University Teknologi Malaysia, 2018

[34] A. R. Nor Zairah, "Multiple Perspectives of Open Source Software Appropriation in Malaysian Public Sector," Ph.D Thesis, University Teknologi Malaysia, 2009.

[35] Parbica, "Recordkeeping for Good Governance Toolkit.," Arch Manuscripts, vol. 36, no. 1, pp. 109-110, 2008.

[36] National Archives of Australia, "Implementing an Electronic Document and Records Management System Checklist," Natl. Arch. Aust., pp. 1-22, 2011.

[37] Change Factory, "EDRMS Project Team Skills Evaluation Checklist," 2012.

[38] S. R. of S. Australia, "EDRMS Procurement and PreImplementation," 2009.

[39] S. Health, "6 Optimization Strategies for Electronic Ddocument Management Systems," 2013.

[40] O. Mosweu, K. Bwalya, and A. Mutshewa, "Examining Factors Affecting the Adoption and Usage of Document Workflow Management System (DWMS) Using the UTAUT Model: Case of Botswana," Rec. Manag. J., vol. 26, no. 1, pp. 38-67, 2016.

[41] L. A. Azlan, "Kerangka Pengurusan Rekod dan Maklumat," Ph.D Thesis, Universiti Kebangsaan Malaysia, 2018.

[42] Dikopoulou and A. Mihiotis, "Records Management: A Key Element for Effectiveness, Accountability and Development in the Greek Public Administration," Int. J. Public Adm., vol. 33, no. 5, pp. 262287, 2010.

[43] H. Abdulkadhim, Mahadi, A. Bakri, and H. Hashim, "Exploring The Common Factors Influencing Electronic Document Management Systems (EDMS) Implementation In Government," ARPN J. Eng. Appl. Sci., vol. 10, no. 23, pp. 17945-17952, 2015.

[44] H. Abdulkadhim, Mahadi, A. Bakri, and H. Hashim, "A Research Framework of Electronic Document Management Systems (EDMS) Implementation," vol. 81, no. 3, pp. 420-432, 2015. 